\title{
PARTIAL HEART BLOCK DUE TO DIGITALIS
}

\author{
BY \\ MAURICE CAMPBELL \\ From Guy's Hospital and the National Hospital for Diseases of the Heart \\ Received June 24, 1942
}

Amongst a series of cases of partial heart block, collected over a period of years, there were some in which treatment with digitalis was mainly or partly responsible. This group involves some special problems that seem worth separate consideration.

The slow pulse, even as slow as 35 in a minute, after the administration of digitalis was one of the original observations of Withering (1785). Much later, but for many years now, it has been recognized that heart block was the cause of the slowest heart rates after digitalis, though some lesser degree of slowing might be due to a direct or vagal effect on the S-A node. According to Cushny (1925, p. 220) the effect of digitalis on the A-V bundle is partly inhibitory through the vagus nerve, but partly, and sometimes mainly with full or long digitalization, a direct effect on the muscle of the A-V bundle.

The slow pulse after digitalis has even passed into literature and, if Mary Webb can be trusted, into the folk-lore of Shropshire and the Welsh border:

"I suppose a dose of foxglove ud put her right, maybe?"

"Ah! Foxglove'll lower the pulse as quick as anything. But you mun be careful. Dunna give her too much. When things get old and worn out they canna stand much of it." (Mary Webb (1924), Precious Bane.)

Mackenzie $(1905, b)$ pointed out that those who already had partial heart block, as shown by a long a-c interval, were more susceptible to this effect of digitalis and were more likely to develop a recognizable degree of heart block. This is confirmed by the present study.

This series was obtained by looking through 10,000 consecutive electrocardiograms taken at Guy's Hospital during the twelve years 1927-38, and adding all others I had remembered to index. There were 141 cases with a prolonged $\mathrm{P}-\mathrm{R}$ interval but no higher degree of block; and the term latent is used as a convenient one to describe this, since it is a true subdivision of heart block that is only made manifest by instrumental methods. There were 29 which also had, at times, partial heart block with dropped beats.

In 26 of these 170, treatment with digitalis was the sole or an important cause of the heart block, and in another 6 it may have been the cause. However, these digitalis cases were not equally distributed: as many as 38 per cent of those with dropped beats were due to digitalis or similar drugs (Table I), but 
only 14 per cent of those with latent heart block ( 26 per cent of those with a P-R interval of $0.26 \mathrm{sec}$. or more, and 12 per cent of those with it between 0.25 and $0 \cdot 20 \mathrm{sec}$.)

TABLE I

Heart Block Caused by or Increased by Digitalis

\begin{tabular}{cc|c|c|c|c}
\hline & $\begin{array}{c}\text { Total } \\
\text { number } \\
\text { of cases }\end{array}$ & $\begin{array}{c}\text { Number due } \\
\text { to or increased } \\
\text { by digitalis }(a)\end{array}$ & $\begin{array}{c}\text { Number } \\
\text { possibly } \\
\text { due to } \\
\text { digitalis }(b)\end{array}$ & $\begin{array}{c}\text { Percenta } \\
\text { due to } \\
\text { digitalis } \\
(a) \text { and }(b)\end{array}$ \\
\hline $\begin{array}{c}\text { Partial heart block with dropped } \\
\text { beats }\end{array}$ & 29 & 11 & 0 & 38 \\
$\begin{array}{c}\text { Latent heart block- . } \\
\text { (a) P-R, } 0 \cdot 26 \text { and above }\end{array}$ &.. & 31 & 7 & 1 & 26 \\
(b) P-R, $0 \cdot 20-0 \cdot 25$ sec. &.$\cdot$ & $\frac{110}{170}$ & $\frac{8}{26}$ & $\frac{5}{6}$ & $\frac{12}{19}$ \\
\hline
\end{tabular}

To write of digitalis without discussing auricular fibrillation is of course to leave out its most important use. The high degree of heart block that is often produced is well known; but here we are not concerned with this aspect of digitalis overdosage.

\section{Cases With Dropped Beats}

The eleven cases with dropped beats are summarized in Table II, and short notes of two of them follow to give more illustrative details.

Case 2. A man, aged 24, with a large heart and mitral stenosis, was admitted to hospital for his second attack of congestive failure. His $\mathbf{P}-\mathbf{R}$ interval at various times without digitalis was $0 \cdot 23-0 \cdot 25 \mathrm{sec}$. He was given 30 minims of tincture of digitalis daily from May 8 to 31 , when block was noted, and four days later there was still 2:1 heart block, partial heart block with dropped beats, and sino-auricular block (Fig. 1). Many records were obtained and the average results are shown below.

2:1 heart block: $\quad$ P-R, 0.25 (almost his normal), dropped beat.

3:2 block: P-R, 0.24, 0.33, d.b.

Single records of lesser degrees of block are shown below.

\begin{tabular}{|c|c|c|c|c|c|c|c|}
\hline $\begin{array}{l}\text { 4:3 block: } \\
\text { 5:4 block: } \\
\text { 6:5 block: } \\
\text { 7:6 block: }\end{array}$ & $\begin{array}{l}\text { P-R, } \\
\text { P-R, } \\
\text { P-R, } \\
\text { P-R, }\end{array}$ & $\begin{array}{l}0.25 \\
0.25 \\
0.26 \\
0.25\end{array}$ & $\begin{array}{l}0 \cdot 31, \\
0 \cdot 31, \\
0 \cdot 31, \\
0 \cdot 29\end{array}$ & $\begin{array}{l}0.39 \\
0.36 \\
0.35 \\
0.32\end{array}$ & $\begin{array}{l}\text { d.b. } \\
0 \cdot 39 \\
0 \cdot 39 \\
0 \cdot 36\end{array}$ & $\begin{array}{l}\text { d.b. } \\
0 \cdot 42 \\
0 \cdot 39\end{array}$ & $\begin{array}{l}\text { d.b. } \\
0.42,\end{array}$ \\
\hline
\end{tabular}

On May 24 his P-R interval had been 0.25 sec., and on May 26 and May 28 his temperature, which had been normal, rose to $100 \cdot 6^{\circ} \mathrm{F}$., suggesting that a return of active carditis was the decisive factor in bringing about his heart block on May 31. His recovery was uneventful and twelve days later the $\mathbf{P}-\mathbf{R}$ interval had returned to $0.25 \mathrm{sec}$.

Case 4. A woman, aged 68, had congestive heart failure and high blood pressure. Treated with 45 minims of tincture of digitalis daily, her pulse rate, which had been $100-80$ on admission, was charted at under 50 on the tenth day, and digitalis was stopped. Dropped beats were recorded, generally with the sequence: P-R, $0.23 \mathrm{sec}$, 0.31 sec., d.b., etc. The heart rate remained about 50 for ten days, and that day 


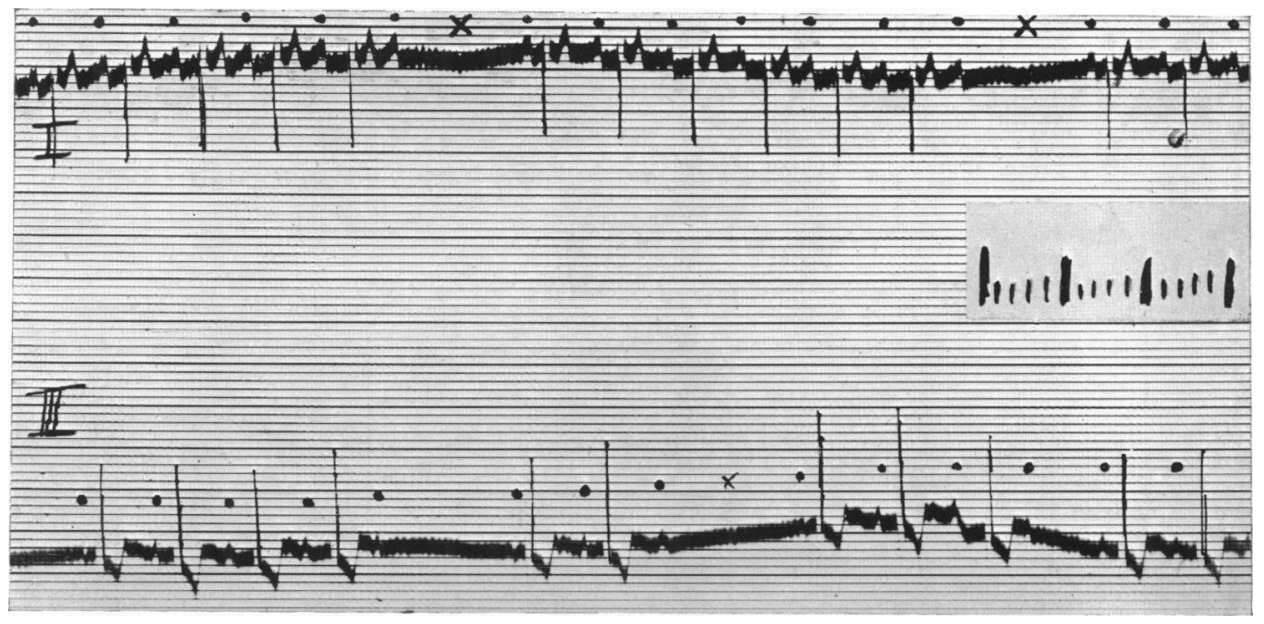

FIG. 1.-Dropped beats after 2, 3, 4, 5, and 6 responses with a lengthening P-R interval. The auricular waves are marked with a dot $(\cdot)$; in three of the longer pauses (marked with a cross) and perhaps in a fourth there is also sinoauricular block. The auricular rate was about 60 . In some other records $2: 1$ heart block was the most usual finding. The time marker is not visible in this print and has been marked on in seconds and fifths. (Case 2).

dropped beats were again recorded with the average sequence of P-R, 0.21 sec., 0.41 sec., d.b., etc. After another seven days, during which the heart rate was regularly over 80 , she was started again on digitalis-this time 2 grains of the leaf daily - and took this regularly, the P-R interval remaining just below $0.21 \mathrm{sec}$., as at first. It is strange that so little digitalis should have produced this and probably infection was the extra cause (see page 135).

\section{Discussion of Cases with Dropped Beats}

All these eleven patients had dropped beats, developing as the first sign of over-digitalization or quickly after this, and disappearing within a few days when it was stopped. Sometimes the dropped beats were only observed for a day or two so that we did not obtain a cardiogram, the patients being under the care of various physicians in different wards. Most often the dropped beats persisted, for from three to five days, and in one case at least they were present the greater part of the time for ten days.

The $P-R$ Interval before Digitalization. In nine cases digitalis was being used in some form; in one, strophanthin; and in one (Case 28), quinidine; the last has been described elsewhere and is only mentioned as evidence that quinidine can produce the same effect (Campbell, 1932). In seven of the remaining ten, the $\mathrm{P}-\mathrm{R}$ interval without digitalis was known and the figures were $0 \cdot 16,0 \cdot 20$, $0 \cdot 21,0 \cdot 21,0 \cdot 22,0 \cdot 24$, and $0.25 \mathrm{sec}$. Thus it was prolonged in all except the first (Case 27) where an unreasonable amount of strophanthin had been given to a patient with pyrexia because of tachycardia after tonsillectomy. This bears out the experience of Mackenzie $(1905, b)$ that it is the patient with latent heart block who is apt to develop dropped beats under digitalis treatment.

Apart from the presence of latent heart block there seemed no other ætiological factor common to all these cases. Rheumatic and syphilitic valvular 
disease and myocardial disease, with and without high blood pressure, were all represented. Probably rheumatic disease formed a smaller proportion than in many conditions because of the tendency of rheumatic hearts to fail with auricular fibrillation, which would automatically exclude them from this study. The effect of digitalis on the P-R interval in these patients is shown in Table II.

TABLE II

The Production of Dropped Beats from Digitalis Therapy

\begin{tabular}{|c|c|c|c|c|c|c|c|}
\hline \multirow{3}{*}{$\begin{array}{l}\text { Case } \\
\text { No. }\end{array}$} & \multirow{3}{*}{$\begin{array}{l}\text { Sex } \\
\text { and } \\
\text { age }\end{array}$} & \multirow{3}{*}{ Diagnosis } & \multicolumn{3}{|c|}{$\mathbf{P}-\mathbf{R}$ interval } & \multirow{2}{*}{\multicolumn{2}{|c|}{ Digitalis treatment }} \\
\hline & & & \multicolumn{2}{|c|}{ with digitalis } & \multirow{2}{*}{$\begin{array}{l}\text { with- } \\
\text { out } \\
\text { digi- } \\
\text { talis }\end{array}$} & & \\
\hline & & & $\begin{array}{l}\text { with } \\
\text { dropped } \\
\text { beats }\end{array}$ & $\begin{array}{l}\text { without } \\
\text { dropped } \\
\text { beats }\end{array}$ & & Daily amount & $\begin{array}{l}\text { No. } \\
\text { of } \\
\text { days }\end{array}$ \\
\hline 2 & m. 24 & $\begin{array}{l}\text { Mitral stenosis; C.F.*; } \\
\text { active carditis. }\end{array}$ & $0.24-0.42$ & - & $0 \cdot 24$ & $\begin{array}{l}30 \text { minims of tinc- } \\
\text { ture }\end{array}$ & 23 \\
\hline 4 & f. 68 & $\begin{array}{l}\text { High blood pressure; } \\
\text { C.F.*; pyrexia. }\end{array}$ & $\begin{array}{l}0.23-0.31 \\
0.21-0.41\end{array}$ & - & $0 \cdot 21$ & $\begin{array}{l}45 \text { minims of tinc- } \\
\text { ture }\end{array}$ & 10 \\
\hline 8 & m. 44 & $\begin{array}{l}\text { High blood pressure; } \\
\text { C.F.*; pyrexia. }\end{array}$ & $0.25-0.29$ & $0 \cdot 25$ & - & 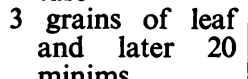 & 18 \\
\hline 9 & f. 66 & $\begin{array}{l}\text { Left ventricular failure } \\
\text { (died). }\end{array}$ & $0.24-0.42$ & $0 \cdot 40$ & - & 6 grains of leaf & 5 \\
\hline 11 & f. 41 & $\begin{array}{l}\text { High blood pressure; } \\
\text { C.F.*; (died). }\end{array}$ & $0 \cdot 18-0.26$ & $0 \cdot 26$ & $0 \cdot 20$ & $\begin{array}{l}45 \text { minims of tinc- } \\
\text { ture }\end{array}$ & 14 \\
\hline 12 & f. 72 & Carcinoma; C.F.* & 一 & $0 \cdot 28$ & - & 69 minims of tinc- & 9 \\
\hline 18 & f. 36 & $\begin{array}{l}\text { Mitral stenosis; acute } \\
\text { rheumatism. }\end{array}$ & $0.23-0.38$ & $0 \cdot 30$ & $0 \cdot 25$ & $\begin{array}{l}\text { 1/80 grain of Nat. } \\
\text { dig., and quini- } \\
\text { dine }\end{array}$ & $? 6$ \\
\hline 19 & f. 58 & $\underset{\text { C.F. }}{\text { High }}{ }^{*}$ blood pressure; & $0 \cdot 19-0 \cdot 38$ & - & $0 \cdot 21$ & $\begin{array}{l}60 \text { minims of tinc- } \\
\text { ture }\end{array}$ & 14 \\
\hline 26 & m. 41 & $\begin{array}{l}\text { Syphilitic A.I.; C.F.*; } \\
\text { pyrexia. }\end{array}$ & - & $0 \cdot 29$ & $0 \cdot 22$ & $\begin{array}{l}60 \text { minims of tinc- } \\
\text { ture }\end{array}$ & 33 \\
\hline 27 & f. 31 & Tonsillectomy; pyrexia & - & $0 \cdot 28$ & $0 \cdot 16$ & $3 / 200$ grain of & 7 \\
\hline 28 & m. 40 & $\begin{array}{l}\text { Thyroidectomy for } \\
\text { hyperthyroidism }\end{array}$ & $0.23-0.46$ & - & $0 \cdot 18$ & $\begin{array}{l}15 \text { grains quini- } \\
\text { dine }\end{array}$ & - \\
\hline
\end{tabular}

Infection or Pyrexia. Although latent heart block was already present in nearly all these cases, and in addition in most of them congestive failure, yet another conditional cause was generally present. Of the ten, two had active rheumatic carditis (one with failure) and four others (three with failure) had some degree of pyrexia, at the time, so that there was probably some infection making the heart more susceptible to digitalis.

In the first two with active rheumatic carditis (Cases 2 and 18) it is not surprising that dropped beats developed as they are liable to occur in this condition, even without digitalis. In a third (Case 27) there had been a fairly severe infection with pyrexia for some time. In her case, however, the amount of strophanthin given was excessive, and in Case 18 also the amount of digitalis was more than is usual and certainly excessive when quinidine was given at the same time. 
Relatively slight infections seem to have had an important effect on the heart in the other three. In one (Case 26) there was "influenza" with a temperature for three days and probably it would hardly have been referred to in the notes if heart block had not developed. The sequence of events is illustrated in Fig. 2. Digitalis was stopped after he had taken 60 minims of the tincture daily for 33 days because the heart rate fell to an irregular 50 a minute (seventh day of fig. 2). For four days it varied between 50 and 80, and one day the P-R interval was $0.29 \mathrm{sec}$. though no dropped beats were recorded. The heart rate, then, remained about 80 ; and after seven days' break digitalis

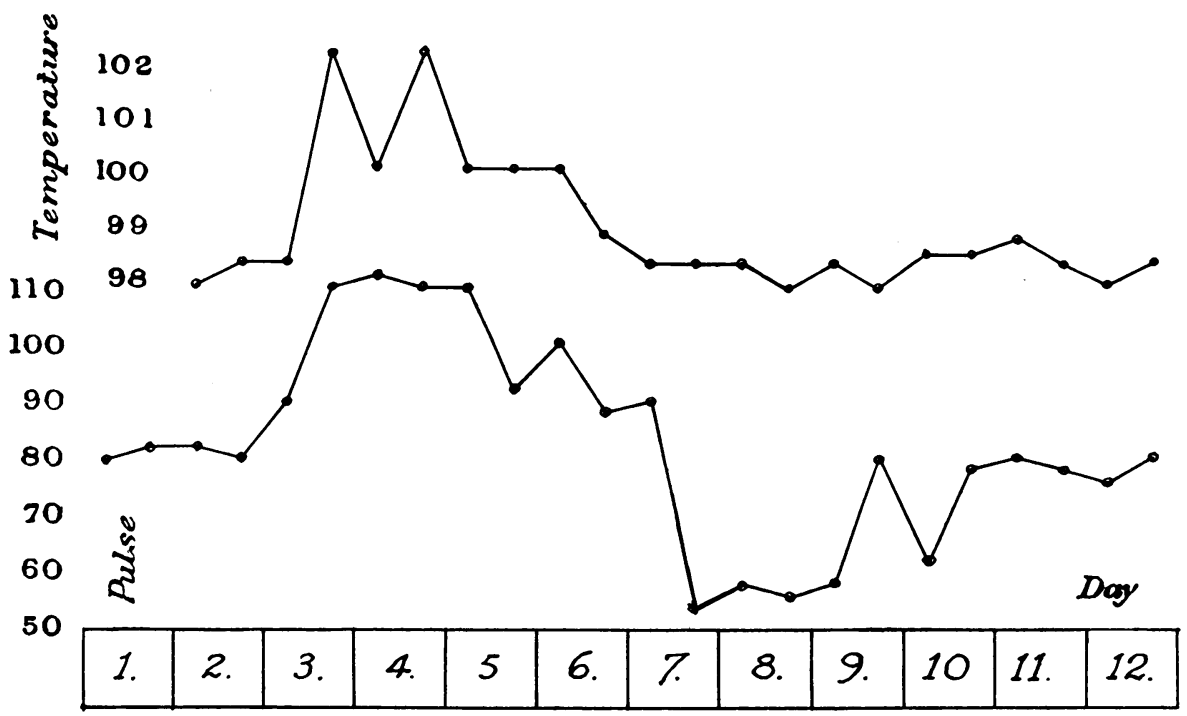

Fig. 2.-A slow pulse due to heart block after a transient infection. The upper line represents the temperature which returned to normal after four days (third to sixth days inclusive). The lower line represents the heart rate which rose with the onset of the temperature but fell sharply five days later (seventh day in fig.) when heart block developed. (Case 26)

was resumed, this time 45 minims daily, and continued until his discharge four weeks later, without any return of dropped beats. On admission with failure and without digitalis, the P-R interval had been 0.22 ; on discharge with digitalis (45 minims daily) but without failure, it was $0 \cdot 23$; and six months before without either, it had been $0 \cdot 18 \mathrm{sec}$.

In the other two the pyrexia was even more trivial and no special cause for it was found. However, in one (Case 8) there was little doubt of the connection because the first time dropped beats were observed there had been a rise of temperature to $99.5^{\circ}$ or $100^{\circ}$ each evening for eight days; and the second time the dropped beats occurred when the rise was about its maximum, reaching $100^{\circ} \mathrm{F}$. every evening; after this there was no more pyrexia, and for the remaining three weeks while he was in hospital he was able to continue with the same amount of digitalis without any recurrence of dropped beats. In the other (Case 4) the connection again seemed a close one, but not proved so clearly, as her treatment was resumed with a smaller dose of digitalis. Two days after her block was first observed her temperature rose to $100^{\circ} \mathrm{F}$. for two days, and again 
for three days at the time the second cardiogram showing block was taken, when she had already been without digitalis for ten days.

In none of the last three cases was there any reason to think that the slight pyrexia was a sign of recurrent, but undiagnosed, rheumatic carditis; one had syphilitic aortic incompetence with congestive failure, and the last two were elderly patients with congestive failure secondary to high blood pressure.

Cushny (1925, p. 90) states that as the temperature is raised experimentally the heart, whether isolated or in the intact animal, becomes more susceptible to digitalis; this being due to a direct action on the muscle as well as to the effect of the acceleration of the heart rate. It seems unlikely, however, that these small rises of temperature in transient infections would be enough to act in this way.

Thus six of the ten cases had some infection at the time of their dropped beats. Two others had hearts that were very gravely damaged as shown by the fact that one (Case 9) died suddenly the next day (see p. 140) and another (Case 11) died three weeks later in spite of all treatment. Cushny (1925, p. 225) says that when the heart is reduced to a state of malnutrition the block through direct muscular action is attained early and easily from digitalis, so that this may have been an additional cause in these two cases.

It seems, therefore, that the presence of infection or of a heart that is almost moribund makes a patient prone to develop partial heart block with dropped beats from an amount of digitalis that would not ordinarily produce this. Three cases supported this directly by being able to take the same amount of digitalis, when they had no pyrexia, without dropped beats developing (Cases 2, 8, and 26).

Accepting this, there were only two patients (Cases 12 and 19) who developed dropped beats under treatment without any additional cause: both had been given 60 minims of tincture of digitalis daily, one for 14 days and the other for 9 days. Perhaps 14 days may be rather longer than many patients can take this amount, but another (Case 26) had taken it for 33 days and even then the onset of an infection was certainly a partial cause of his dropped beats. The quantity of digitalis that was being taken by all these cases is discussed later (see p. 139).

The Effect of Digitalis on the $P-R$ Interval. This is shown in Table II. The average $\mathrm{P}-\mathrm{R}$ interval before digitalis therapy was $0.21 \mathrm{sec}$. In seven cases there was a record of the $P-R$ interval about the time of the dropped beats, but at a moment when they were absent and there was latent heart block without dropped beats. The average figure was $0.29 \mathrm{sec}$.

Where there were dropped beats they generally occurred after two normal, if slow, responses, i.e. 3:2 heart block (and this was the only group where there were enough for statistical treatment). In three the $\mathrm{P}-\mathrm{R}$ interval of the response before the dropped beat was moderately prolonged, the average figure being 0.22 sec., 0.29 sec., dropped beat. In the other six the $\mathrm{P}-\mathrm{R}$ interval of the response before the dropped beat was much longer, and the average figures were $0.22 \mathrm{sec}$., $0.41 \mathrm{sec}$., dropped beat. It did not seem possible to find any reason for the difference between these two groups; in fact one patient (Case 4) after 
an interval of five days varied just as much as these two very different sets of figures.

The $\mathrm{P}-\mathrm{R}$ interval at a time when there were no dropped beats was on the average about half-way between the two $P-R$ intervals that came before the dropped beat; but this was only an average of very divergent figures, and in individual cases it might be little longer than the first P-R interval or nearly as long as the second.

The first $\mathrm{P}-\mathrm{R}$ interval after the dropped beat was on the average much the same as the $P-R$ interval without any digitalis, and here there was much closer agreement in individual cases.

\section{Latent Heart Block without Dropped Beats}

In addition to the 11 cases with dropped beats, there were 15 others where digitalis treatment lengthened the conduction time, and another 6 (making 21 in all) where this was probable, but not quite certain, as there was no record of the usual P-R interval without digitalis. In 8 of these the $21, \mathrm{P}-\mathrm{R}$ interval was $0.26 \mathrm{sec}$. or more; some details of these cases are shown in Table III.

TABLE III

Prolongation of the P-R Interval to 0.26 Sec. AND above by Digitalis

\begin{tabular}{|c|c|c|c|c|c|}
\hline \multirow{2}{*}{$\begin{array}{l}\text { Case } \\
\text { No. }\end{array}$} & \multirow{2}{*}{$\begin{array}{l}\text { Sex } \\
\text { and } \\
\text { age }\end{array}$} & \multirow{2}{*}{ Diagnosis } & \multicolumn{2}{|c|}{$\mathbf{P}-\mathbf{R}$ interval } & \multirow{2}{*}{$\begin{array}{l}\text { Daily amount of } \\
\text { digitalis }\end{array}$} \\
\hline & & & $\begin{array}{l}\text { with } \\
\text { digitalis }\end{array}$ & $\begin{array}{l}\text { without } \\
\text { digitalis }\end{array}$ & \\
\hline 45 & f. 15 & Mitral stenosis $\quad \ldots \quad \ldots$ & $\begin{array}{l}0 \cdot 36 \\
0.40\end{array}$ & $\begin{array}{l}0 \cdot 28^{*} \\
0 \cdot 28^{*}\end{array}$ & $\begin{array}{l}45 \text { minims tincture } \\
3 \text { grains leaf }\end{array}$ \\
\hline 48 & f. 18 & $\begin{array}{l}\text { Acute rheumatism; aortic in- } \\
\text { competence. }\end{array}$ & $0 \cdot 31$ & $0 \cdot 20$ & $\begin{array}{l}5 \text { gr. of leaf for several } \\
\text { days }\end{array}$ \\
\hline 57 & m. 54 & $\begin{array}{l}\text { Mitral stenosis; congestive } \\
\text { failure. }\end{array}$ & $0 \cdot 34$ & $0 \cdot 26 \dagger$ & $\begin{array}{l}1 / 100 \text { gr. Nat. dig. for } \\
\text { several days }\end{array}$ \\
\hline 41 & m. 68 & $\begin{array}{l}\text { High blood pressure; auricular } \\
\text { flutter. }\end{array}$ & $0 \cdot 30$ & $0 \cdot 24$ & $\begin{array}{l}1 / 150 \text { gr. Nat. dig. for } \\
7 \text { days (see text) }\end{array}$ \\
\hline 61 & m. 51 & Left ventricular failure $\quad$.. & $0 \cdot 28$ & $0 \cdot 18$ & $\begin{array}{l}75 \text { minims tincture for } \\
21 \text { days }\end{array}$ \\
\hline 38 & m. 58 & $\begin{array}{l}\text { High blood pressure; con- } \\
\text { gestive failure. }\end{array}$ & $0 \cdot 28$ & $0 \cdot 20$ & $\begin{array}{l}80 \text { minims tincture for } \\
28 \text { days }\end{array}$ \\
\hline 53 & f. 47 & $\begin{array}{l}\text { High blood pressure; con- } \\
\text { gestive failure. }\end{array}$ & $0 \cdot 27$ & - & 45 minims daily \\
\hline 46 & m. 60 & $\begin{array}{l}\text { Heart failure; coronary } \\
\text { thrombosis. }\end{array}$ & $0 \cdot 26$ & $0 \cdot 21$ & $\begin{array}{l}1 / 200 \text { gr. Nat. dig. for } \\
18 \text { days }\end{array}$ \\
\hline
\end{tabular}

* Some years later it was 0.36 without digitalis.

$\dagger$ Still on some digitalis.

The $P-R$ Interval before Digitalization. Some degree of heart block before digitalis treatment seemed the most important factor in allowing digitalis to increase this significantly. Where the $P-R$ interval was increased to $0.26 \mathrm{sec}$. or above by digitalis, only one of the seven where the P-R interval was known had one of less than $0.20 \mathrm{sec}$. without digitalis; his was $0.18 \mathrm{sec}$. and he was given 75 minims of the tincture daily for 21 days (Case 61). In the eighth the P-R 
interval without digitalis was not known. The average figures for the $\mathbf{P}-\mathbf{R}$ intervals before and after digitalis were 0.22 and $0.30 \mathrm{sec}$. respectively.

Where the P-R interval was increased to something less than $0.26 \mathrm{sec}$. by digitalis, it was above $0.18 \mathrm{sec}$. without digitalis in all of the eight, except in one with acute infection and severe congestive failure and in one during pregnancy; in both these it was only $0.16 \mathrm{sec}$. There were five others in this group where the $\mathrm{P}-\mathrm{R}$ interval without digitalis was not known. The average figures before and after digitalis were $0 \cdot 19$ and $0 \cdot 22 \mathrm{sec}$. respectively.

Other Aetiological Factors. The presence of latent heart block before digitalization was the main factor that was common to nearly all of the cases. The type of heart disease seemed of no significance and all varieties were present in different patients; nine of the twenty-one had valvular disease, nearly always rheumatic, and the other twelve had primary myocardial disease, six of these with high blood pressure and three at least with disease of the coronary arteries.

Heart failure was naturally present in the great majority as it is the main indication for digitalis. The reasons for its administration in four of the other six without failure was tachycardia and cyanosis (Case 45), some undue dyspnœa during pregnancy, auricular flutter (Case 41), and frequent extrasystoles; in the other two there seemed to have been no adequate reason for the prescription of digitalis.

The other factor that seemed common to these cases-at any rate to those where the $\mathrm{P}-\mathrm{R}$ interval was most increased-was a rather bad prognosis. There were eight in whom it was lengthened to $0.26 \mathrm{sec}$. or more, and two of these were not followed for long enough to know the outlook. Of the other six, one did well, one had acute pulmonary œdema in the fifth year, and four died after $1,1,4$, and 8 years respectively. As digitalis was generally used for a failing heart, and heart failure with normal rhythm has a worse prognosis than failure with auricular fibrillation, one could not expect the patients to live for very long, but these figures are worse than might be expected.

Infection or Pyrexia. Active infection was much less in evidence as a cause than in the cases with dropped beats, but was present in three. One had infective endocarditis and congestive failure. A second, a girl of 18, to whom 5 grains of digitalis leaf has been given daily for several days without any adequate reason had a recurrence of acute rheumatism at the time (Case 48; P-R from 0.20 to $0.31 \mathrm{sec}$.). A third, a boy of 7 , was critically ill with congestive failure due to acute myocarditis and acute nephritis following tonsillitis: probably, he owed his life to digitalis treatment, though the $\mathrm{P}-\mathrm{R}$ interval lengthened from 0.16 to $0.21 \mathrm{sec}$; this last may partly have been due to his myocarditis, as some of the inversion of the $T$ waves certainly was, but seemed more closely related to the time of his treatment with digitalis than of his active infection. A fourth was recovering from recent broncho-pneumonia, but this seemed rather the exciting cause of his congestive failure than of his partial heart block (Case 57).

One case where the P-R interval was not lengthened by digitalis was striking in this connection. A woman, aged 56, suffering from the after effects of tonsillitis and broncho-pneumonia some months before and from auricular 
fibrillation that was probably due to old hyperthyroidism, had a P-R interval of $0.13 \mathrm{sec}$. after treatment with 45 minims of tincture of digitalis daily for five weeks; fibrillation had stopped after a few days treatment with digitalis and may possibly have been paroxysmal. Four months later she was again admitted with an acute rheumatic infection, most unlike rheumatic fever and with no other signs of cardiac involvement, and while she was being treated with sodium salicylate only, her P-R interval was $0.22 \mathrm{sec}$; presumably this was due to the infection, and it had been only $0.13 \mathrm{sec}$. when she was treated with digitalis.

\section{Digitalis}

The Amount of Digitalis. In few of these patients could the increase in the heart block be attributed to an amount of digitalis that was obviously excessive, and curiously enough the largest amounts had sometimes been given where there seemed no indication for digitalis therapy (Cases 18, 27, and 48).

In the ten where dropped beats developed, three had large doses of digitalis1/240 grain of Nativelle's digitaline, t.i.d., and some quinidine, probably for 6 days (Case 18, with acute rheumatism);1/200 grain of strophanthin, t.i.d., for 7 days (Case 27, with tachycardia and pyrexia after tonsillectomy); and 6 grains of the leaf daily for 5 days (Case 9, with left ventricular failure). Certainly in the first two there seemed no reason why digitalis should have been given. Three others had 60 minims of tincture daily for 9, 14, and 33 days, and even then the last only developed dropped beats with an intercurrent infection (Case 26). Of the remaining four, two had the standard dose of 45 minims daily and two had only 30 and 20 minims daily. In the last two these amounts had been taken for 23 and 18 days respectively; and recurrent infection (once rheumatic and once of unknown origin) was almost certainly the precipitating cause, as later when they had no pyrexia they were able to take the same amount without the production of dropped beats.

In the group of eight, with the greater increase of conduction time but no dropped beats, four had amounts that were large -5 grains of the leaf daily for no apparent reason (Case 48, with recurrent rheumatism); 1/100 grain of Nativelle's digitaline daily for several days (Case 57); 75 minims of the tincture daily for 21 days (Case 61); and 80 minims of the tincture daily for 28 days (Case 38); these two last, however, were both large heavy men.

In the other four of these eight, and in the thirteen with the lesser increase in the conduction time, the amount of digitalis was certainly not unusually large. In two only, who had about 60 minims daily, was it above 45 minims of the tincture daily (or its equivalent), and in five it was less than this.

The cause, therefore, rarely lay in excessive amounts of digitalis, and this might be expected where most cases were being treated at hospital, though it is only fair to add that during the years in question massive digitalization has not been a popular method of treatment at Guy's Hospital-and, in my opinion, rightly so. In general, during continued treatment, failing to give an adequate amount of digitalis is much more common than giving too much.

Other Symptoms. Little has been said about other symptoms produced by 
the overdose with digitalis. Price (1941) states that they are anorexia, nausea, vomiting, and diarrhœa, in addition the very varied effects on the rhythm. Unfortunately in this series of cases special notes were not taken about the general condition of the patient, and no useful conclusions can be drawn about the relative stages at which the general symptoms and the slower pulse occurred. Nausea and vomiting were noted most, but it is surprising how often there was no note of other symptoms, and how the house officer in charge did not stop the exhibition of digitalis until partial heart block with dropped beats was observed. It is also surprising that extrasystoles were not noted; no single case was observed where they were seen in the cardiographic record at the time of full digitalization, though of course they would have been difficult, if not impossible, to recognize clinically when there were dropped beats.

Indications for Digitalis in Heart Block. The old contraindications to digitalis therapy have gradually been swept away, and Cushny $(1925$, p. 233) in lending his authority to this view agrees that digitalis may be useful even when there is complete heart block, but still looks with doubt at its use when there is partial block. Obviously the risk of increasing this must be taken into account; but when failure is present, digitalis should always be used in adequate amounts until experience shows that the drawbacks, if any, outweigh the advantages.

These results have made it clear that when there is congestive failure with latent heart block, an increase in this, even with dropped beats, is liable to occur after reasonable amounts of digitalis. There seemed, however, no great drawback even in cases where dropped beats were produced, and in general the block passed off quickly within two to four days of the digitalis being stopped, though once it persisted for ten days. As might be expected from its slow absorption and slow effect, there was sometimes a higher degree of block the day after digitalis had been stopped, and this would be a danger if the condition was not recognized. Freedom from ill-effects is dependent, therefore, on the heart block being recognized with reasonable speed, but care and knowledge are always needed to make the most effective use of digitalis.

One of these patients died suddenly, soon after block had been observed and digitalis stopped; but she was extremely ill before and had, post-mortem, advanced disease of the coronary arteries with a badly scarred ventricle, so that sudden death was an ever-present risk; it is possible but far from certain that digitalis may have caused her death by producing ventricular fibrillation; it is probable that it had already prolonged her life in previous attacks.

When failure is not present, there are fewer indications for digitalis and the recognition of partial heart block may decide against it. This, however, must not be made a general rule, and one case is of special interest because the high degree of block might have prevented treatment with digitalis in a girl who was greatly benefited and continued taking it most of the time for several years. She had high grade mitral stenosis with much cyanosis and dyspnœa. Dozens of electrocardiograms between 1931 and 1938 never showed a shorter P-R interval than $0.26 \mathrm{sec}$; in 1932,45 minims of the tincture daily increased it from 0.28 to $0.36 \mathrm{sec}$., and in 1933 a period of treatment with 3 grains of the leaf daily increased it to $0.40 \mathrm{sec}$. (see Fig. 3). Gradually, during the course 

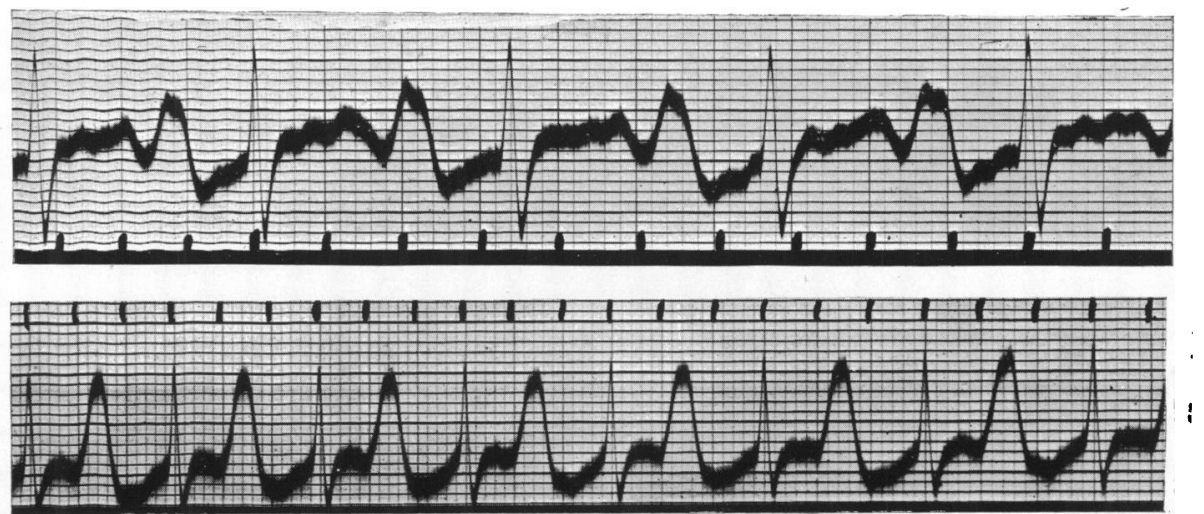

Fig. 3.-Latent heart block, present for eight years without a dropped beat being noted.

(A) Above. 13/5/31. The shortest P-R interval of $0.28 \mathrm{sec}$.

(B) Below. 24/11/33. The P-R interval had been increased from 0.28 to $0.40 \mathrm{sec}$. by digitalis, but later it increased to $0.36 \mathrm{sec}$. without digitalis.

The $\mathbf{P}$ wave was always large, but in (B) it is exaggerated as the tachycardia and the still longer $P-R$ interval have superimposed it on the $T$ wave. (Case 45)

of these seven years, the P-R interval rose from 0.26 to 0.36 sec., even when she was not taking digitalis. It is surprising that at no time (and she attended hospital regularly for years) was a dropped beat observed (Case 45).

Mackenzie $(1905, a)$ described a somewhat similar case where the a-c interval was two-fifths of a second and remained so for twelve years; no dropped beats were observed except for one short period about the middle of the time. He emphasized that digitalis must be used whenever indicated, even in partial heart block, and that sometimes when there was effective slowing the conductivity might even be improved. Cohn and Fraser (1913) have suggested, as an explanation of how digitalis may help in some cases of mitral disease, that it may act by lengthening the A-V interval and thus facilitating the passage of blood from auricle to ventricle.

\section{Summary AND CONCLUSIONS}

Digitalis therapy is one of the commonest causes of partial heart block with dropped beats, and a common cause of a P-R interval that is much prolonged without dropped beats. Other factors, however, are generally present, and the most important of these seems to be some lengthening of the $\mathrm{P}-\mathrm{R}$ interval before digitalis therapy; even then, a concurrent infection is often the immediate cause of the dropped beats. In a series of cases of partial heart block nearly 40 per cent of those with dropped beats were being given digitalis, and 15 per cent of those with latent heart block.

The most essential prerequisite was some prolongation of the $\mathrm{P}-\mathrm{R}$ interval before treatment. In those with partial heart block and dropped beats, and in those with latent heart block it averaged $0.21 \mathrm{sec}$. Only in three of twenty-three was the P-R interval below $0.18 \mathrm{sec}$.; in these three it was $0.16 \mathrm{sec}$., and in two of them there was acute infection also. When there were no dropped beats, 
the $P R$ interval was on the average increased to $0.26 \mathrm{sec}$. When there were dropped beats, there were most often two responses before the dropped beat, and the lengthening P-R intervals averaged $0.22 \mathrm{sec}$., $0.37 \mathrm{sec}$., dropped beat, etc. This, however, was the average of very varied figures, which averaged $0.22,0.29$, dropped beat, etc., in three, and $0.22,0.41$, dropped beat, etc., in six patients. No special difference could be found between the groups with these different responses. Apart from the presence of latent heart block the ætiology of the underlying heart disease did not seem of importance, though naturally congestive failure was present in the majority, as this was usually the indication for digitalis.

The presence of a concurrent infection seemed the next most important factor. When there were dropped beats, more than half had some active infection at the time. Sometimes this was a severe infection such as active rheumatic carditis, but often it seemed of a trivial nature, and it was only because digitalis could be taken at other times without producing dropped beats or because the rise of temperature ran so closely parallel to their onset that one could be sure of the connection. When there was latent heart block, an active infection was less often present, but was noted as the cause in a few cases. In others where there was no infection but a heart that was very seriously damaged (as shown by the patient's death within a relatively short time) this seemed an additional factor making the conduction time more sensitive to digitalis than usually.

Large amounts of digitalis were rarely the cause. Three of these cases were taking amounts that would generally be thought excessive (and curiously enough two of these had acute infections at the time and there seemed no reason why any digitalis should have been given); seven had amounts that were large, but quite reasonable; and twenty-two were taking amounts that were average or sometimes even small.

In general, there seemed to be no severe ill-effects, even when there were dropped beats; and the block passed off quickly (within two or three days), but, of course, this immunity is dependent on the heart block being recognized quickly.

There seems no reason why the chance finding of latent heart block should prevent adequate treatment with digitalis where this is indicated, though naturally the case should be watched even more carefully than usual.

\section{REFERENCES}

Campbell, M. (1932). Lancet, 2, 1157.

Cohn, A. E., and Fraser, F. R. (1913). J. Pharm. exper. Ther., 5, 512.

Cushny, A. R. (1925). The Action and Uses in Medicine of Digitalis and its Allies, London, 1 st edit.

Mackenzie, J. (1905, a). Brit. Med. J., 1, 520.

- (1905, b). Ibid., 1, 587.

Price, F. W. (1941). A Textbook of the Practice of Medicine, Oxford University Press, 6th edit., p. 868.

Withering, W. (1875). An Account of the Foxglove and some of its Medical Uses, Birmingham and London. 